\title{
LATAR BELAKANG BUDAYA DAN PENGARUHNYA TERHADAP RELASI KLIEN DENGAN KONSELOR DALAM LAYANAN KONSELING DI INDONESIA
}

\author{
Oleh : \\ Prof. Dr. Firman. MS. Kons \\ ( Jurusan Bimbingan dan Konseling Fakultas Ilmu Pendidikan Universitas Negeri \\ Padang)
}

Email : firman@konselor.org

\begin{abstract}
Various problems experienced counselors baga in helping clients solve problems in environment plural society of Indonesia. Clients come from a particular culture, tend to make the culture as a frame of reference in the act. Strategy-based socio-cultural counseling can be an option to help clients solve their everyday problems. Socialcultural-based counseling will not release the client from the principle that human beings as subjects as well as the purpose in every step and change efforts. Client relations with the counselor in counseling services as an act of communication mediated by the production of meaning and negotiation of meaning systems in culture. The relationship between counselor and client through the communication will be able to increase social awareness against kelien counselor. Attention to the client and their culture is intended to utilize all its potential for thinking about personal interests, groups and organizations in creating a more prosperous life.
\end{abstract}

\section{A. Pendahuluan}

Masyarakat Indonesia berasal dari latar belakang budaya yang beragam. Kemajemukan tersebut merupakan kekayaan dan sekaligus dapat dipandang sebagai ancaman timbulnya berbagai masalah yang dapat mengarah munculnya disintegrasi bangsa. Persentuhan antar budaya dalam kemajemukan masyarakat Indonesia akan selalu terjadi, karena permasalahan silang budaya terkait dengan pola berfikir dan bertindak kelompok sosial tertentu. Individu dan kelompok sosial akan selalu 
mengacu kepada nilai-nilai dalam kebudayaan masyarakat mereka sendiri. Sesuatu yang menjadi masalah bagi individu dalam latar budaya tertentu, ada kalanya tidak menjadi masalah bagi individu lainnya yang berbeda budaya.

Permasalahan silang budaya dalam pergaulan masyarakat Indonesia memerlukan perhartian utama dalam upaya mewujudkan kehidupan sejahtera di lingkungan masyarakat. Guru pembimbing atau konselor yang bertugas dalam pemberian layanan konseling perlu memahami perilaku individu sebagai upaya menjembatani permasalahan silang budaya dalam layanan yang diberikannya. Kondisi ini didasari oleh kebudayaan suatu masyarakat yang merupakan perwujudan kebermaknaan individu-individu tersebut dengan lingkungannya. Setiap klien dalam suatu masyarakat dengan latar budaya berbeda memandang permasalahan yang mereka alami secara unik. Konstruksi social serta pemahaman terhadap permasalahan yang dialaminya telah lama dibangun bersama keluarga serta masyarakat dimana mereka berada. Transmisi budaya yang berlangsung sepanjang kehidupan individu tersebut membuat keunikan dalam memandang kebermaknaan jalan kehidupannya perlu dipahami secara hakiki oleh konselor.

Individu, kebudayaan serta masyarakat dimana klien berada akan selalu berkembang sejalan dengan perkembangan pola pikir dan kebutuhan manusiaitu sendiri. Koentjaraningrat (2000 :1994) menjelakan kebudayaan dapat dimaknai sebagai keseluruhan sistem gagasan, tindakan dan hasil karya manusia yang diperoleh melalui hasil belajar dalam kehidupan masyarakat, yang dijadikan milik manusia itu sendiri. Berkaitan dengan hal itu, tingkah laku individu sebagai anggota masyarakat terikat dengan kebudayaan yang diwujudkan dalam berbagai pranata. 
Pranata tersebut berfungsi sebagai mekanisme kontrol bagi tingkah laku manusia untuk memenuhi kebutuhannya.

Individu beserta masyarakatnya dalam budaya masyarakat majemuk akan mengalami berbagai permasalahan menghadapi berbagai perubahan. Persentuhan nilai-nilai budaya sebagai manifestasi dinamika kebudayaan tidak jarang menyebabkan berbagai permasalahan. Permasalahan silang buaya yang dialami individu dalam masyarakat majemuk tidak jarang bersumber dari masalah komunikasi, kesenjangan tingkat pengetahuan, status sosial, ekonomi, geografis, adat kebiasaan, yang tidak jarang penghalang terciptakanya consensus dalam menyelesaikan kehidupan bersama.

Kondisi Indonesia sebagai masyarakat majemuk selalu mengalami perubahan dalam berbagai aspek kehidupan. Kontak budaya antar kelompok etnis tertentu mewujudkan perubahan tata nilai atau konflik nilai. Berbagai bentuk permasalahan silang budaya, harus dapat dipandu dan dikendalikan melalui layanan konseling, baik melalui seting sekolah maupun luar sekolah.

Di sisi lain, pengenalan klien dengan potensi serta kebutuhannya, dalam latar budaya tertentu sangat diperlukan oleh konselor dalam pengembangan seluruh dimensi kemanusiannya. Prayitno (2004) menjelaskan dimensi kemanusian klien yang harus dikembangkan melalui layanan konseling adalah : (1) dimensi keindividualan, (2) dimensi kesosialan, (3) dimensi kesusilaan, dan (4) dimensi keberagamaan. Pemahaman klien dari latar budaya berbeda dalam upaya pengembangan dimensi kemanusiannya tersebut sangat bermanfaat baik dalam proses maupun untuk mencapai tujuan akhir layanan konseling. 


\section{B. Kebudayaan dan Tingkah Laku Klien dalam Masyarakat Majemuk.}

Kebudayaan merupakan pola kehidupan bersama masyarakat yang bersifat dinamis untuk memenuhi kebutuhannya. Masyarakat Indonesia yang majemuk mempunyai berbagai kebudayaan dan pola perilaku yang berbeda satu dengan lainnya. Kebudayaan yang dibawa klien dari lingkungan masyarakatnya, dijadikan dasar untuk membatasi serta membolehkan mereka melakukan sesuatu yang dianggap pantas dan tidak pantas. Kepantasan klien berperilaku ditentukan oleh sistem nilai budaya mereka masing-masing. Sistem nilai yang telah dibangun oleh klien melalui proses sosialisasi dengan lingkungannya, berfungsi mengontrol serta mengarahkan mereka berperilaku.

Kontak budaya, laju urbanisasi yang begitu cepat serta krisis multi dimensi yang sedang dihadapi bangsa Indonesia, menimbulkan dampak yang cukup serius di segala bidang kehidupan klien. Melonggarnya kesadaran kolektif, melemahnya control social serta semakin tidak efektifnya kehidupan sehari-hari dialami klein dalam kehidupannya merupakan satu dampak negatif dari perubahan social budaya. Kondisi ini tidak jarang menyebabkan berbagai permasalahan dalam masyarakat, diantaranya : perkelahian, Narkoba/Dadah, perceraian, putus sekolah dan sebagainya.

Layanan konseling tidak dapat dilepaskan dari kondisi sosial budaya klien itu sendiri. Sebelum layanan konling diberikan, para konselor diharapkan telah memahami berbagai kondisi sosial budaya klien. Pemetaan permasalahan serta kondisi sosial budaya klien sangat membantu keefektifan meberikan layanan dan bimbingan yang dibutuhkan klien. 
Klien dalam masyarakat majemuk sering dihadapkan oleh pola perilaku yang suatu saat disetujui oleh beberapa kelompok, di sisi lain dicela oleh kelompok lainnya. Perbedaan nilai tersebut tidak jarang menimbulkan berbagai permasalahan yang membutuhkan layanan konseling dalam pemberian pemahaman dan pengalaman dominan untuk membentuk kepribadian. Pengalaman seseorang klien melalui layanan dan bimbingan konseling seharusnya tidak hanya sekedar bertambah dalam proses pembentukan kepribadiannya, namun juga terintegrasi dengan pengalaman sebelumnya. Kepribadian klien dengan segala potensinya akan memberikan corak khas pada perilaku dan pola penyesuaian diri mereka dengan lingkungannya.

Hambatan-hambatan potensial dimiliki oleh klien dari masyarakat majemuk untuk memanfaatkan segala potensinya menyelesaikan permasalahan, ditentukan banyak banyak aspek, diantaranya : Struktur sosial serta kebudayaan berbeda akan menghasilkan pola dan proses pembuatan keputusan sosial yang berbeda. Masyarakat Indonesia yang majemuk tersebut, memiliki berbagai kegiatan dan pranata khusus, dimana setiap kultur merupakan sumber nilai yang memungkinkan terpeliharanya kondisi kemapanan dalam kehidupan masyarakatnya.

Klien berasal dari suatu kebudayaan tertentu, cenderung menjadikan kebudayaannya sebagai kerangka acuan dalam berperilaku. Kondisi ini sekaligus akan mengukuhkan jati dirinya sebagai anggota masyarakat yang memiliki karakteristik tertentu. Perbedaan antar budaya, justru bermanfaat dalam mempertahankan dasar identitas diri dan integrasi sosial klien dalam masyarakat tersebut. Pluralisme masyarakat dalam tatanan sosial, agama, budaya dan suku bangsa masyarakat Indonesia telah berakar dari sejak dahulu kala. Kebhinekaan budaya yang 
dapat hidup berdampingan secara damai merupakan kekayaan yang tak ternilai harganya dalam pengembangan budaya nasional. Keunggulan suatu nilai budaya bukan berarti tidak dihiraukannya nilai-nilai budaya lainnya, melainkan kurang dijadikannya oleh klien sebagai acuan dalam bersikap dan berperilaku dibandingkan dengan nilai budaya yang telah diunggulkannya.

Permasalahan yang sering dihadapi klien dalam masyarakat majemuk adalah adanya persentuhan dan saling hubungan antara kebudayaan suku bangsa dengan kebudayaan daerah, nasional dan internasional. Diantara hubungan-hubungan ini yang paling kritis adalah hubungan antara kebudayaan suku bangsa dan umum local di satu pihak dan kebudayaan nasional serta internasional di pihak lain. Pemaksaan untuk merubah tata nilai atau upaya penyeragaman budaya seringkali dapat memperkuat penolakan klien terhadap layanan konseling yang diterimanya.

Klien tidak jarang merasa curiga dan tidak percaya diri sehingga tidak berani menyampaikan berbagai gejolak yang mereka alami kepada konselor. Apalagi menyangkut permasalahan yang dianggapnya tidak baik untuk diketahui orang lain. Keraguan tersebut menyebabkan sebagian besar klien memendam berbagai persoalan hidup yang akhirnya menimbulkan berbagai masalah psikologis maupun fisiologis. Kondisi ini pada akhirnya menyebabkan kehidupan sehari-hari klien tidak efektif.

Mencermati perbedaan budaya dalam masyarakat manejemuk sebagai hambatan bagi klien dalam menyelesaikan masalahnya. Layanan konseling yang diterima klien seharunya dapat meningkatkan pengetahuan dan pengalaman klien dalam menyelesaikan masalahnya. Penyelesaian permasalahan silang budaya dapat dilakukan dengan membangun kehidupan multi kultural yang sehat. Kondisi ini 
dilakukan dengan meningkatkan toleransi dan apresiasi antarbudaya, yang dapat diawali dengan peningkatan tingkat pengetahuan klien terhadap kebhinekaan budaya, dengan berbagai model pengenalan ciri khas budaya tersebut..

Strategi konseling berbasis budaya, dapat menjadi pilihan karena koneling berbasis adat tidak akan melepaskan diri dari prinsip bahwa manusia adalah faktor utama, sehingga manusia harus selalu merupakan subyek sekaligus tujuan dalam setiap langkah dan upaya perubahan.

\section{Relasi Klien dengan Konselor dalam Layanan Konseling}

Relasi klien dan konselor dalam layanan konseling dijembatani oleh komunikasi. Apabila ditinjau lebih lanjut, komunikasi dalam kajian budaya dipahami sebagai tindakan produksi makna serta negosiasi sistem-sistem makna tersebut oleh individu dalam kebudayaannya. Posisi konelor dalam layanan konseling ditentukan oleh pengetahuan dan kemampuannya untuk menegosiasikan sistem-sistem makna tersebut dengan kliennya dalam berbagai konteks budaya. Salah satu cara memahami hubungan kebudayaan dengan tindakan adalah memahami konstruksi sosial yang telah dibangun oleh klien melalui proses sosialisasi dengan lingkungan masyarakatnya.

Relasi antara konselor dengan klien melalui komunikasi akan dapat meningkatkan kepeduli sosial. Kondisi ini diwujudkan dengan memberi perhatian terhadap klien, terutama ditujukan untuk memanfaatkan segala potensi yang dimilikinya untuk memikirkan kepentingan pribadi, kelompok, dan organisasi tertentu. 
Djamaluddin Ancok (2003) menjelaskan pengembangan kepeduliaan sosial diperlukan adanya : (1) pikiran positif pada orang lain. Bila seseorang memiliki sifat demikian dia akan melihat orang lain sebagai bagian dari kebahagiaan hidupnya sendiri. Selain itu dia selalu melihat sisi positif dari hal-hal yang dilakukan dan dipikirkan oleh kliennya, (2) kemampuan berempati. Sifat ini dimiliki oleh orang yang bisa merasakan apa yang dirasakan oleh orang lain. Kepekaan perasan yang dimilikinya membuat dia mudah merasakan kegembiraan dan kesusahan orang lain. Orang yang tidak memiliki kemampuan berempati biasanya sangat sulit untuk bisa berhubungan baik dengan orang lain, (3) komunikasi transformasional. Sifat ini dimiliki oleh orang yang selalu memilih kata-kata yang enak didengar telinga di dalam berbicara pada orang lain. Bila terjadi perbedaan pendapat antara dia dengan orang lain, dia tetap memilih kata-kata yang menyejukkan hati dan pikiran dalam menanggapi perbedaan tersebut, (4) berorientasi sama sama puas (win-win). Orang yang memiliki sifat demikian dalam interaksinya dengan orang selalu ingin membuat orang lain merasa gembira dan dia juga gembira. Orang yang demikian memiliki rasa respek pada orang lain, (5) sifat melayani (serving attitude). Orang yang memiliki sifat demikian ini sangat senang melihat orang lain senang dan sangat susah melihat orang lain susah. Sifat ini adalah lawan dari sikap egois yang hanya mementingkan diri sendiri, atau golongannya sendiri. Orang yang memiliki sifat melayani, kalau menjadi pimpinan, dia bukan minta dilayani tetapi melayani kepentingan orang yang dipimpinnya, (6) kebiasaan apresiatif. Orang yang memiliki sifat ini suka memberikan apresiasi pada apa yang dilakukan oleh orang lain. Dengan apresiasi yang diberikan pada orang lain membuat orang lain merasa dihargai. Seorang 
pimpinan memberikan apresiasi kepada bawahannya biasanya akan menumbuhkan rasa bermakna di dalam kehidupan kerjanya.

Klien berhubungan dengan konselor dalam layanan konseling didasari oleh motif-motif tertentu. Motif-motif tersebut tidak terlepas dari budaya mereka sendiri. Thibault dan Kelley (Rachamat, 1997) dalam teori pertukaran social menjelaskan seseorang melakukan hubungan secara sukarela dan bertahan dalam hubungan tersebut selama memuaskan ditinjau dari ganjaran yang diperoleh dibandingkan dengan biaya yang dikeluarkan dari hubungan tersebut.

Ganjaran merupakan nilai positif yang diperoleh klien melalui hubungan social dengan konselor dalam layanan konseling. Ganjaran yang mungkin diperoleh klien dari proses hubungan social tersebut, adalah : berupa penerimaan social, informasi, cinta, pengakuan social dan status. Sedangkan cost atau biaya merupakan akibat negatif yang dikeluarkan klien melalui hubungan sosial dengan konselor dalam layanan konseling. Biaya dalam hubungan social dapat berupa waktu, konflik serta kecemasan, keruntuhan harga diri, tenaga dari kondisi lain yang dapat menimbulkan efek yang tidak menyenangkan.

Kelangsungan hubungan sosial antara konlor dengan klien ditentukan oleh perbandingan antara ganjaran yang diperoleh serta cost yang harus dikeluarkan untuk hubungan tersebut. Seseorang klien tidak segan-segan menghabiskan waktu tenaga serta harga diri untuk mendapatkan pengalaman, keterampilan agar perbaikan kualitas hidupnya di masa mendatang. Apabila pengalaman, keterampilan yang diperoleh sesuai dengan tenaga, waktu dan harapan yang diinginkan terwujud maka hubungan tersebut akan bertahan. Apabila cost atau biaya yang dikeluarkan klien 
lebih besar dari reward atau ganjaran diperoleh dari sesesuatu hubungan dengan konselor akan upaya pemutusan hubungan social.

Sehubungan dengan hal itu, konselor dalam pemberian layanan terhadap klien perlu mengidentifikasi minat, atau bakat dan motif-motif klien yang berasal dari latar budaza berbeda tersebut, mengigat berfariasinya karakteristik klien. Konselor dalam pemberian layanan konseling dalam seting sekolah dan luar sekolah dituntut memperhatikan klien secara individual dan kelompok beserta keunikan social budaya mereka masing-masing.

Pemeliharaan dan memperteguh hubungan antara klien dengan konselor dalam seting sekolah dan luar sekolah memerlukan tindakan tertentu untuk mengembalikan keseimbangan. Rachmat (2000) menjelaskan empat factor yang amat penting dalam memelihara keseimbangan hubungan, yaitu :

(1) keakraban, merupakan kebutuhan akan kasih sayang. Hubungan antar pribadi akan terpelihara apabila klien dengan konselor sepakat menetapkan tingkat keakraban yang telah terbina.

(2) kesepakatan siapa yang akan mengontrol siapa dan bilamana. Jika dua orang mengambil pendapat berbeda sebelum mengambil kesepakatan siapa yang harus berbicara lebih banyak dan siapa menentukan dan dominan akan terjadi konflik, karena masing-masing mau berkuasa dan tidak ada mau mengalah,

(3) ketepatan respon, artinya klien harus diikuti oleh respon konselor yang sesuai. Pertanyaan harus disambut dengan jawaban, lelucon dengan tertawa dan sebagai. Respon biasanya berkenaan dengan pesan-pesan verbal dan non verbal. Jika pembicaan serius dari seseorang dijawab dengan main-main, ungkapan 
serius dijawab dengan olok-olok maka hubungan antar pribadi akan mengalami

keretakan. Respon yang ditampilkan individu dalam hubungan social terasebut dapat dikategorikan ke dalam respon konfirmasi dan diskonfirmnasi. Respon konfirmasi akan memperteguh hubungan atar peribadi, misalnya dengan memberikan pengakuaan perasaan positif, respon meminta keterangan, respon setuju, sedangkan respon yang bersifat diskonformasi merusak hubungan antar pribadi, misalnya dengan memberikan respon sekilas, respon kosong, respon yang tidak relevan, respon kontradiktif dan sebagainya.

(4) keserasian suasana emosional ketika berlangsungnya hubungan. Jika seseorang berinteraksi dengan seseorang dan individu lainnya dalam suasana emosinal yang berbeda maka interaksi tersebut tidak akan stabil dan besar kemungkinan salah satu fihak akan mengakhiri hubungan atau merubah suasana emosional yang sedang dirasakannya.

Relasi antara konselor dengan klien akan bersifat dangkal apabila kurang terbinanya hubungan interpersonal dengan baik. Kondisi ini menyebabkan layanan konseling tidak optimal dalam membina klien untuk dapat menjalani kehidupannya secara efektif.

\section{Kesimpulan}

Berdasarkan uraian tersebut dapat disimpulkan hal sebagai berikut:

a. Nilai budaya yang tumbuh subur dalam masyarakat selalu berakar dari kearifan lokal. Strategi konseling berbasis sosial budaya dapat menjadi pilihan untuk membantu klien mewujudkan kehidupan efektif sehari-hari. Konseling berbasis 
sosial budaya tidak akan melepaskan diri klien dari prinsip bahwa manusia sebagai subyek sekaligus tujuan dalam setiap langkah dan upaya perubahan.

b. Relasi klien dengan konselor dalam layanan konseling dijembatani oleh komunikasi sebagai tindakan produksi makna serta negosiasi sistem-sistem makna tersebut dalam kebudayaannya. Relasi antara konselor dengan klien melalui komunikasi akan dapat meningkatkan kepeduli sosial konselor terhadap kelien.

c. Perhatian terhadap klien beserta kebudayanya ditujukan untuk memanfaatkan segala potensi yang dimilikinya untuk memikirkan kepentingan pribadi, kelompok, dan organisasinya dalam mewujudkan kehidupan efektif sehari-hari. 


\section{DAFTAR KEPUSTAKAAN}

Firman dan Elisna Sandora (2010) : Efektifitas Pembinaan Anak Jalanan Melalui Rumah Singgah. Padang: Balitbang Propinsi Sumatera Barat.

Imran Manan (2001) : Antropologi Pendidikan Suatu Pengantar. Jakarta : Departemen Pendidikan dan Kebudayaan Direktorat Jenderal Pendidikan Tinggi.

Imran Manan (2000) : Dasar-dasar Sosial Budaya Pendidikan. Jakarta : Departemen Pendidikan dan Kebudayaan Direktorat Jenderal Pendidikan Tinggi.

Kartono, Kartini. (2010) : Patologi sosial I. Jakarta: Rajawali Press.

Kazdin, A.E. (2009) : Behavior modification: In applied settings $6^{\text {th }}$ ed. Belmont, CA: Wadsworth/Thomson Learning.

Koentjaraningrat. (2007) : Pengantar antropologi pokok-pokok etnografi II. Jakarta: Rineka Cipta.

, (2000) : Masyarakat Desa di Indonesia. Jakarta : Lemabaga Penerbit Akultas Ekonomi UI.

, (2000): Manusia dan Kebudayaan di Indonesia. Penerbit : Jambatan Jakarta, , (2000): Kebudayaan Mentalitas dan Pembangunan. Pernerbit: PT. Gramedia, Jakarta.

Miltenberger, R.G. (2011): Behavior modification: Principles and procedures $3^{\text {rd }}$ ed. Belmont CA: Wadsworth/Thomson Learning.

Prayitno, Erman Amti (2004) : Dasar-dasar Bimbingan dan Konseling. Jakarta : Perbit Rineka Cipta. 